trade-marked goods is extremely dubious. Consumers know best the prices of the things they purchase most often. Closely related to this anti-monopoly argument is the contention that the consumer benefits from resale price maintenance because loss-leader tactics are eliminated..$^{8}$ This argument also rests upon the assumption of consumer irrationality. Whether the consumer should be protected by law from his own irrational behavior about variations in price is still an open question.

The basic issue of the Miller-Tydings Act is whether it should be the policy of the United States to encourage the growth of retail combinations. It is true that there is an express provision in the Miller-Tydings Amendment and in the fair trade acts against horizontal combinations, but unless the spirit of these provisions was violated, the fair trade movement would make little economic sense. The Department of Justice and the Federal Trade Commission have claimed that the great majority of fair trade agreements in interstate commerce are probably in violation of the provision against horizontal combinations. But the anti-trust enforcement agencies do not have sufficient funds to investigate all the contracts made and to enforce the provision against horizontal combinations. ${ }^{59}$ If they did, the fair trade acts would in effect become something very different, and of much less economic interest and importance.

\title{
TRADE ASSOCIATION STATISTICS AND THE ANTI-TRUST LAWS
}

Most trade associations in the United States have engaged at one time or another in collecting and distributing industry statistics. The movement is usually said to date from the publication in IgI2 of Mr. A. J. Eddy's book The New Competition, which had as its thesis that "[t]rue competition begins with

${ }^{8}$ One of the early bills introduced to legalize resale price maintenance contracts in interstate commerce (the Stephans Bill introduced in the 64th Congress) was presented as a bill "to protect the public against dishonest advertising and false practices in merchandising." The Fair Trade League was the chief sponsor of the bill and at the annual meeting of the League the following dialogue took place:

Mr. Arend: Is it in the best form to get what we want? Has it a false caption? It has as I look at it.

Mr. Geissler: I don't think it is ambiguous. I thought the sops included were advantagestrading points, so to speak.

And later Mr. Arend said, "I am skeptical about the consumer arguments .... I don't like the sham in it." FTC, op. cit. supra note 18 , at $45-47$.

The most careful analysis of the economic advantages to the consumer of resale price maintenance was made by Prof. F. W. Taussig; he decided that the consumer arguments were not to be taken seriously enough to warrant a conclusion favorable to resale price maintenance. 6 Am. Econ. Rev. Supp. I5 (zgr6).

There have been several statistical studies of the effect of fair trade agreements on prices and the studies, while inconclusive, have all indicated that prices of the same products are higher in fair trade states than in the noy-fair trade states. See FTC, op. cit. supra, at XIV-L.

${ }^{59}$ See note $5 \mathbf{x}$ supra. 
the development of conditions that tend to eliminate secrecy in bidding and charging."

Under "open competition" plans, co-operative exchange of one or more of three types of information is supposed to eliminate cutthroat methods attributed to ignorance of true market conditions. It is thought that sellers with no reliable information as to their competitors' prices frequently are victimized by buyers who falsely represent that they have received lower offers elsewhere. This "phantom" or "ghost" competition is sought to be diminished by filing and circulating the prices of all sellers. ${ }^{2}$ It is supposed also that unwarranted price cuts result from sellers' unawareness of their costs. Improved cost accounting methods and dissemination of average cost information are intended to remedy that situation. ${ }^{3}$ Distribution of cost information also is thought to encourage more efficient operation by enabling comparisons of individual with group or industry costs. ${ }^{4}$ Overproduction, resulting from inadequate knowledge of the supply and demand situation in the industry, is still another alleged source of price instability. This ostensibly is to be corrected by collecting and distributing figures on unfilled orders, inventories, and production or proposed production. 5

Although this movement has had disinterested supporters, ${ }^{6}$ and, in time of war and depression, even governmental encouragement, ${ }^{7}$ in many instances "open competition" is nothing more than a device to aid an industry in avoiding risks of price competition. Whenever a number of firms propose jointly to restrict supply and raise the price in an industry they are confronted with two major problems. These are: (I) how to make known to members the price or production policies to be pursued without betraying the fact that an unlawful restrictive scheme is in force; and (2) how to secure adherence in the face of inevitable financial incentives to "overproduce" or "undercut" the noncompeti-

1 Eddy, The New Competition 86 (rgr4).

2 Burns, The Decline of Competition 60 (1936).

3 Jones, Trade Association Activities and the Law $64-65$ (I922); Burns, op. cit. supra note 2 , at $47-49$.

4 See Pearce, Trade Association Survey (U.S. Temporary National Economic Committee, Monograph I8, I94I) at 285: "Most cost statistics serve the dual purpose of enlivening the member's consciousness of the relation of cost to price and of stimulating his interest in the better and more economical management of his business."

5 Jones, op. cit. supra note 3 , at 50-5x; Burns, op. cit. supra note 2 , at $55^{-60}$.

6 Herbert Hoover, as Secretary of Commerce, in Ig22 wrote a lengthy letter to Attorney General Daugherty requesting clarification of the legal status of activities he regarded as helpful not only "to the Department and to the commercial world but to the public generally." Reprinted in Jones, op. cit. supra note 3 , Appendix J, at 324 .

IIn World War I the government relied on trade associations to supply needed industrial information. See Jones, op. cit. supra note 3 , at 53. This precipitated a substantial grow th of the movement. Pearce, op. cit. supra note 5 , at I2. The NRA gave trade association statistics unprecedented status in the I930's. For discussion of statistical operations in several industries under the codes, see Whitney, Trade Associations and Industrial Control 6I-I44 (I934). 
tive price. In meeting these problems the statistical operations of "open competition" have been helpful in a variety of ways.

Reports of prices, costs, and production can provide a simple mechanism for communicating to members the policies they are to follow. ${ }^{8}$ Recipients of a report concerning average prices may be expected to raise prices that are below the reported average. ${ }^{9}$ Data as to average costs of a group of typical firms may be used in the same way, particularly when a normal profit is included in the "cost." "Wo When freight rates from a central point to destinations throughout the country are also distributed, the member firms are enabled to quote uniform delivered prices." Cost accounting programs that require the use of an "estimating manual" ${ }_{12}$ or otherwise cause components of total cost to be carried at a standard amount having no relation to actual $\cos ^{\mathrm{T}} \mathrm{T}^{3}$ have an obvious utility in this connection. Estimates of future production of individual producers can serve as a means of assigning quotas; ${ }^{14}$ and production data can be distributed with the understanding that output is to be reduced whenever stocks exceed a stated ratio to sales. ${ }^{15}$

8 Edwards, Maintaining Competition 25-26 (1949).

${ }^{9}$ See indictment, United States v. Philadelphia Wholesale Cleaners and Dyers Ass'n, U.S.D.C.E.D. Pa., Dkt. No. 55150 (April 25, r949); indictment, United States v. Brake Lining Manufacturers Ass'n, U.S.D.C.S.D. N.Y., Dkt. No. C I26/207 (Aug. 2I, 1947); complaint, United States v. National Container Ass'n, U.S.D.C.S.D. N.Y., Dkt. No. 8-3I8 (April 20, I940).

xo Burns, op. cit. supra note 2, at 50-52. The author remarks that where this has been done " 'average costs' . . . become merely a suggested selling price, uniform for all, and provide a means by which to define and detect price cutting. ..." See Pearce, op. cit. supra note 4, at 290: "Cost studies exhibiting average costs, typical costs, and the like no doubt are used by some members of associations as a basis in determining prices. ..."

II This was done by the Maple Flooring Manufacturers Ass'n. Consult Maple Flooring Manufacturers Ass'n v. United States, 268 U.S. 563, 57I (1925), where the Court refers to the practice of antecedent associations.

12 See FTC v. United Typothetae of America, 6 F.T.C. 345 (I923). The FTC enjoined use of "the Standard Guide," at one time called "the Price List," which actually suggested prices to be charged based on actual average hour costs for the various operations, plus a recommended 25 per cent profit. Standardized costs for a multitude of operations were compiled in the book. For a full treatment of accounting manuals, see Pearce, op. cit. supra note 4, at 258-77. See complaint, United States v. Stevenson, Jordan, and Harrison, U.S.D.C.S.D.N.Y., Dkt. No. IO-213 (Aug. 22, I940).

${ }^{13}$ Attorney General Daugherty, answering Secretary Hoover's letter, note 6 supra, referred to the "strong effort ... . made by some lumber associations to take as a basis for estimating costs of production a uniform charge for stumpage." Reprinted in Jones, op. cit. supra note 3 , Appendix J, at 332. Burns, op. cit. supra note 2 , at 49 , describes the attempt of cotton-textile, stove and furniture manufacturers to induce members to include raw materials at replacement cost; the stovemakers association even suggested percentages of the costs of material to be added for breakages, for plating, for loss and waste, salesmen's costs, and other items.

${ }^{2}$ See Hartford Empire Co. v. United States, 323 U.S. 386, 427 (I945). The Glass Container Ass'n was broken up because its statistical committee furnished forecasts of probable future production which were communicated to members at meetings and were treated as quotas, deviation from which was discouraged.

${ }^{15}$ See Edwards, op. cit. supra note 8, at 26. 
Price filing most directly aids the enforcement of price agreements when there is an accompanying agreement to adhere to the filed prices for a fixed period. This gives others an opportunity to exercise persuasion or intimidation upon those who threaten to break from the going price. ${ }^{16} \mathrm{But}$ even if no waiting period is required, the mere fact that the price cutter is identified will have a restrictive effect. ${ }^{17}$ Members have also been kept in line by circulating a list of prices and representing that lower prices would be a violation of state unfair-sales statutes. ${ }^{28}$ Production control, which generally is an accessory to enforcement of the price agreement, may be achieved by circulating and analyzing production and inventory figures so that members are induced to curtail production. ${ }^{\mathrm{x}}$ False or misleading market information has been disseminated for the purpose of indicating an expected shortage, thereby deterring immediate price reductions. ${ }^{20}$

While the courts have not been unaware of these harmful aspects of tradeassociation statistics, they have assumed that typically the statistics, by increasing knowledge in the market, are beneficial to competition. ${ }^{2 x}$ For this rea-

${ }^{26}$ This type of price filing agreement was frequently found during the period of NRA codes. See Whitney, op. cit. supra note 7, at I05 (refined sugar), and at I26 (woolen goods). For discussion of some evils of the adherence requirement, see Handler, Construction and Enforcement of the Federal Anti-trust Laws (U.S. Temporary National Economic Committee Monograph 38, I94I), at 23.

${ }_{77}$ Edwards, op. cit. supra note 8, at 27.

${ }^{8}$ Indictment, United States v. Tennessee Retail Grocers Ass'n, U.S.D.C.M.D. Tenn. Nashville Div. Dkt. No. I0223 (April 27, I942); complaint, United States v. Rhode Island Food Council, Inc., U.S.D.C.R.I., Dkt. No. I57 (Dec. I9, I94r).

19 See American Column \& Lumber Co. v. United States, 257 U.S. 377 (I92r); complaint and consent decree, United States v. West Coast Lumbermen's Ass'n, U.S.D.C.S.D. Cal. Cent. Div., Dkt. No. I488-Y (April 16, I94I); indictment, United States v. Western Pine Ass'n, U.S.D.C.S.D. Cal. Cent. Div., Dkt. No. 14522 (Sept. I8, I940).

${ }^{30}$ See American Column \& Lumber Co. v. United States, 257 U.S. 377, 405-8 (I92I); complaint, United States v. Washington Wholesale Grocers Ass'n, U.S.D.C.W.D. Wash. No. Div., Dkt. No. 538 (July $x$, 1942).

ar Most of the law relating to "open competition" is found in a line of five leading Supreme Court cases. At the time the first two of these, American Column \& Lumber Co. v. United States, 257 U.S. 377 (xg2x), and United States v. American Linseed Oil Co., 262 U.S. $37 \mathrm{x}$ (1923), were decided, the Court was not sufficiently impressed with the need for market information to allow the associations to continue their statistical programs. Justices Holmes, Brandeis and McKenna, dissenting in the American Column \& Lumber case, did take the position that full knowledge of business facts was a worthy objective. This became the majority position in the next two trade association cases, Maple Flooring Manufacturers Ass'n v. United States, 268 U.S. 563 (I925), and Cement Manufacturers Protective Ass'n v. United States, 268 U.S. 588 (r925), with Justices Taft, Sanford and McReynolds of the majority in the earlier cases dissenting. While there are some distinctions on the facts between the two pairs of cases, actually only Justice Van Devanter sided with the majority in both. Justice Stone in the Maple Flooring case, at 582 , clearly states the assumption that now underlies judicial evaluation of trade-association statistical plans: "It is the consensus of opinion of economists and of many of the most important agencies of Government that the public interest is served by the gathering and dissemination, in the widest possible manner, of information with respect to the production and distributing cost and prices . . . of market com- 
son, "open competition" plans are presumptively valid, and the prosecution has had the burden of proving that in particular cases cost, price, or production information has actually been used as part of a restrictive scheme. In this framework, the trade association cases are price-fixing cases in which the underlying scheme is to be found inferentially, with the statistical activities providing one body of evidence from which the inference is to be made. ${ }^{22}$ From the points of view of both the associations and the anti-trust agencies this arrangement is unsatisfactory. With respect to the former, the fact that each case requires an inference from many circumstances makes it exceedingly difficult for an association to know in advance how far it may go in its statistical operations. ${ }^{23}$ With respect to the latter, the difficult burden of proving an underlying restrictive arrangement would be eliminated if courts evaluated more critically the assumption that cost, price, and other trade information of the kind dispensed by trade associations is useful to competition. Examination of some prohibitions frequently recited in the cases will emphasize the difficulties of the associations; a survey of the law relating specifically to price, cost and production statistics will indicate that the underlying assumption of utility to competition is questionable.

It is well established that a trade association statistical program must abide by four "rules": (I) the information must be fully available to all interested parties; (2) the identity of particular contributors must not be disclosed; (3) supervisory powers of the association must not be excessive; and (4) the data must be released without comment, analysis, or subsequent discussion at asso-

modities. ..." This attitude is manifest in Sugar Institute v. United States, 297 U.S. 553 (1936), in which the Court, while enjoining many of the Institute's practices, permitted reporting of current and future prices.

22 In cases where there was evidence of uniform pricing methods and price identity as well as statistical exchange, FTC cease and desist orders have been upheld. U.S. Maltsters Ass'n v. FTC, I52 F. 2d I6I (C.A. 7 th, I945) (Commission's finding of conspiracy to restrain competition held to be supported by evidence of uniformity of delivered prices, use of a single basing point in computing delivered prices, and exchange of freight rate and other trade information); Milk \& Ice Cream Can Institute v. FTC, I52 F. 2d 478 (C.A. 7th, I946) (Commission's finding of unlawful combination to restrain competition held to be supported by evidence of uniformity of delivered prices, a freight equalization plan, and compilation of freight rate factors); Fort Howard Paper Co. v. FTC, I56 F. 2d 899 (C.A. 7th, 1946) (Commission's finding of conspiracy in restraint of competition held to be supported by evidence of price uniformity, a two zone pricing system, and the gathering of information by the association); FTC v. Cement Institute, 333 U.S. 683 (I948) (Commission's finding of restraint of competition held to be supported by evidence of agreement to use a multiple basing-point pricing system, price and bid uniformity, preparation and distribution of freight rate books, and imposition of sanction against recalcitrant members).

${ }^{23}$ See Handler, op. cit. supra note $x 6$, at Ig: "The generality of these decisions, the primacy given to the facts, and the studied refusal of the Court to formulate any generalizations applicable to other states of facts, have limited their practical value to those interested in discovering the permissive limits of the statistical activities of trade associations. Uncertainty is not removed by a doctrine which makes each case a law unto itself." 
ciation meetings. ${ }^{24}$ Nevertheless, complete compliance does not guarantee a plan's legality any more than does occasional departure from the rules assure the government's success.

In the American Column \& Lumber ${ }^{25}$ and Linseed Oil ${ }^{26}$ cases secrecy in reporting of the data was a particularly objectionable feature of the plans. "With intimate knowledge of the affairs of other producers ... the subscribers went forth to deal with widely separated and unorganized customers necessarily ignorant of the true conditions." ${ }_{27}$ On the other hand, the fact that statistics gathered by the Maple Flooring Association were "given wide publicity" was considered highly significant by the Court in a later case. ${ }^{28}$ While an inroad upon the rule was made in the Sugar Institute case where the Court allowed certain data of a confidential nature (probably cost figures) to be withheld from outsiders, ${ }^{29}$ the requirement, as to prices at least, remains intact. The importance of publicity as a test of the legality of an association's operations may best be explained as a result of looking to established information-dispensing agencies for guidance in judging "open competition." Since the essence of the operation of such agencies is full and open disclosure of information, failure to furnish published reports to both buyers and sellers was thought sufficient to show a purpose beyond the mere supplying of information..$^{30}$

The publicity requirement may be met without removing the possibility of using the published information in connection with a restrictive scheme. Members of the association will continue to know, for example, what is the "going price" and who has deviated from it. From the anti-trust standpoint, therefore, the absence of secrecy should not insure a finding of lawful behavior. On the other hand, since nonavailability to outsiders is only one circumstance that may evidence combination, if on the basis of all the evidence the court is unconvinced of the existence of an unlawful conspiracy, a high degree of non-

24 That the data should be accurate is too evident to discuss at length. Reports of fictitious or "washed" sales, elimination of low prices in reporting of sales, and suppression of facts concerning production designed to mislead as to price or production conditions are to be avoided. See Jones, op. cit. supra note 3 , at $6 \mathrm{x}$; Kirsh and Shapiro, Trade Association in Law and Business 57 (1938).

${ }^{25}$ American Column \& Lumber Co. v. United States, 257 U.S. 377 (Ig21).

${ }^{26}$ United States v. American Linseed Oil Co., 262 U.S. 37I (I923).

${ }^{27}$ Ibid., at 389-90.

${ }^{28}$ Maple Flooring Manufacturers Ass'n v. United States, 268 U.S. 563, 573 (1925).

${ }^{29}$ Sugar Institute v. United States, 297 U.S. 553 (I936). The Court states that the purchasing and distributing trade do not have a legitimate interest in certain data of a "confidential character," and full publicity of such information might be prejudicial to the refiners. Ibid., at 604.

${ }^{30}$ See American Column \& Lumber Co. v. United States, 257 U.S. 377, 4 II (192I), where the Court said: "One distinguishing and sufficient difference is that the published reports go to both seller and buyer, but these reports go to the seller only. ..."; United States v. American Linseed Oil Co., 262 U.S. 37x, $39^{\circ}$ (I923), where the Court concluded: "The situation here questioned is wholly unlike an exchange where dealers assemble and buy and sell openly. ..." 
availability will be tolerated. In a recent case, Tag Manufacturers Institute $v$. FTC, the Court of Appeals for the First Circuit found that the information was made sufficiently available merely by being open for inspection at the New York office of the Institute's co-ordinator. ${ }^{3 r}$

An important factor in the American Column \& Lumber case was that the association sent out to members information as to production, sales, stocks, and prices in which the identity of producers, sellers, and purchasers was revealed. ${ }^{32}$ Approval of the statistical plan of the Maple Flooring Association resulted, at least in part, because names of purchasers and identification of mills making reports were omitted. ${ }^{33}$ Complete disclosure of this kind probably was regarded as significant by the Supreme Court for two reasons: (I) ordinarily businessmen do not so completely inform their rivals as to details of their business;34 and (2) disclosing the identity of customers and the specific facts of each sale do not improve the general value of the statistics, that is, other agencies dispensing trade information do so without breaking down the figures so as to identify particularly concerns. ${ }^{35}$ The Court in the Cement Manufacturers case, ${ }^{36}$ however, allowed the practice of reporting specific job contracts between identified parties. In all other respects the Court was satisfied that the association's program did not evidence a restrictive purpose. The Court rationalized its result by finding that this departure from what it considered the normal practice of exchanges could be explained as an attempt to avoid losses to which sellers of cement were subject due to the peculiar terms on which cement was sold.37

Price leadership and the policing of price and production agreements may be

${ }^{3 x}$ I 74 F. $2 d 452$ (1949). The Commission had found that purchasers and consumers located outside the New York area had not benefited from the price lists. The court concluded: "We are clearly of the opinion that if the reporting agreement is otherwise unobjectionable, it cannot be said to have become illegal for failure of the subscribers to make the information generally available. ..." Ibid., at 462 .

${ }^{32}$ American Column \& Lumber Co. v. United States, 257 U.S. 377, 394-96 (I92I).

${ }_{33}$ Maple Flooring Manufacturers Ass'n v. United States, 268 U.S. 563, 573 (r925).

34 See American Column \& Lumber Co. v. United States, 257 U.S. 377, 4IO (I92I): "Genuine competitors do not make daily, weekly and monthly reports of the minutest details of their business to their rivals...."; United States v. American Linseed Oil Co., 262 U.S. $37 \mathrm{I}, 3^{89}$ (I923). The plan "took away theirfreedom of action by requiring each to reveal the intimate details of its affairs."

${ }^{35}$ See Kirsh and Shapiro, op. cit. supra note 24 , at $57-58$.

${ }^{36}$ Cement Manufacturers Protective Ass'n v. United States, 268 U.S. 588 (Ig25).

37 Cement was always sold for use in a specific piece of construction. The obligation was that the manufacturer should furnish and the contractor take only what was required for that particular job. The purchaser was to pay nothing until after delivery, he was not obliged to take the cement unless he chose to, and he was not held to the contract price if the market declined. On the other hand, in case of a market advance, the seller could be held for delivery of the full amount required by the job contract. Thus the contractor took no risk in contracting with several manufacturers for a single job and taking delivery of more than was required for it alone if the market price rose. Filing of specific job contracts was allegedly for the purpose of preventing this kind of exploitation. 
more difficult in the absence of identification of particular firms, but this does not necessarily mean that there is no such joint undertaking. Enforcement and price guidance still may be forthcoming from the association headquarters which usually will know the identity of reporting firms. One solution, from the anti-trust standpoint, is to require that tabulations be made by an independent agency; but even if this is done the association's power to audit the records of its members gives it access to the same information..$^{8}$

While complete restriction of the power to audit is exceptional, it has consistently been recognized that too complete supervisory power suggests the likelihood of coercion. In the Linseed Oil case the Court found that the members deposited with an "autocratic Bureau" large funds "to insure their obedience" to the reporting agreement. ${ }^{39}$ The significance of such provisions is that they represent a surrender of independence inconsistent with true competitive behavior. However, where, as in the Tag Manufacturers case, the court finds the plan as a whole innocent, the mere presence of a penal provision will not imply an unlawful undertaking. ${ }^{\circ}$ Thus, supervision necessary to the effective operation of the reporting plan will be allowed, and this may include the imposition of pecuniary fines. But absence of "drastic supervision" does not necessarily spell out competitive behavior, since the enlightened self-interest of participants may be enough to insure their obedience to a restrictive plan. ${ }^{4 x}$

The American Column \& Lumber case made it clear that comment upon, and analysis and discussion of, trade data was an indication of group pressure to act in conformity with a joint plan..$^{42} \mathrm{It}$ is evident that where this is done more than mere statistical information is disseminated-significant clues may be dispensed as to what prices members should charge or what quantities they should produce. The clear-cut prohibition of comment on statistics contained in American Column \& Lumber was somewhat eroded by the Court in Maple Flooring. Discussion of cost statistics was permitted and no significance was attached to the circumstance that "upon occasion the trend of future prices be-

${ }^{38}$ Some consent decrees have specifically restricted the auditing or examining of records or accounts. United States v. West Coast Lumbermen's Ass'n, U.S.D.C.S.D. Cal. Cent. Div., Dkt. No. I488-Y (April r6, r94r); United States v. Western Pine Ass'n, U.S.D.C.S.D. Cal. Cent. Div., Dkt. No. I389-RJ (Feb. 6, x94r).

${ }_{39}$ United States v. American Linseed Oil Co., 262 U.S. 37x, 389 (x923).

40 Tag Manufacturers Institute v. FTC, I74 F. 2d 452, 46r (r949). The court was careful to point out that violators of the reporting agreement were not subject to "penalties," but were assessed "liquidated damages" where the breach resulted in "probable actual damages." But, regardless of this distinction, "[i]f the reporting commitments they are designed to buttress are otherwise lawful, the agreement does not become a violation of the anti-trust laws ... merely because the reporting plan is accompanied by a penalty provision...."

${ }_{4 x}$ See American Column \& Lumber Co. v. United States, 257 U.S. 377, 399 (I92I), where the Court observes: "The sanctions of the plan obviously are, financial interest, intimate personal contact, and business honor, all operating under the restraint of exposure of what would be deemed bad faith and of trade punishment by powerful rivals."

42 Ibid, at 398-99. 
came the subject of discussion outside the meetings." 43 This is but another demonstration of the fact that decisions in the trade association cases are inferences from conglomerations of facts, no one of which is controlling. Evidence of comment and discussion will always be important, but, like evidence of other practices, not necessarily decisive.

II

In the Maple Flooring case the association had obeyed all the general rules announced in the earlier cases, and, with respect to price information, "All reports of sales and prices dealt exclusively with past and closed transactions." 44 For some time it was thought that this expressed the law concerning open-price systems: current and future price reporting was conclusive or, at least, presumptive evidence of unlawful behavior; while information about prices no longer in effect, which could not be the basis for fixing current prices, was not. The Sugar Institute decision, however, strongly indicated that the "past and closed transactions" doctrine was not to be taken too seriously. In that case the district court had, in an exhaustive and carefully written opinion, found illegal an elaborate price reporting scheme. 45 The Supreme Court affirmed, relying mainly on the circumstance that the members were required to adhere, without deviation, to the filed price and terms; but in so doing it eliminated the part of the decree enjoining the reporting or relaying of current or future prices..$^{6}$ The special circumstance that sugar was traditionally sold on "moves" which were precipitated by advance announcement of a price rise perhaps limits the force of the decision to such a situation; but at least three interpretations were made by the experts. ${ }^{47}$ The anti-trust division persists in regarding information of past prices as somehow safer than current or future price reports..$^{48}$ However, the court in the Tag Manufacturers case refused to distinguish between past and

${ }_{43}$ Maple Flooring Manufacturers Ass'n v. United States, 268 U.S. 563, 575 (I925).

44 Ibid., at 573 .

45 United States v. Sugar Institute, I5 F. Supp. 8I7 (N.Y., I934).

${ }_{4}^{6}$ Sugar Institute v. United States, 297 U.S. 553, 603 (1936).

${ }_{47}$ The decision is closely limited in this connection to the particular factual situation; Handler, op. cit. supra note I6, at 22. While the Court speaks of historic usage, it sanctions a plan of future price reporting that other industries may be able to adopt. Fly, Observations on the Anti-trust Laws, Economic Theory and the Sugar Institute Decisions: I, 45 Yale L.J. ${ }_{1339}$ I $_{3} 63$ ( 1936 ). The decision expressly authorizes the distribution of current price information where it is not for the purpose of fixing prices. Donovan, The Effect of the Decision in the Sugar Institute Case upon Trade Association Activities, 84 U. of Pa. L. Rev. 929, 939 (I936).

${ }^{8}$ Consent decree, United States v. Western Pine Ass'n, U.S.D.C.S.D. Cal. Cent. Div., Dkt. No. ${ }^{3} 89-$-RJ (Feb. 6, x94x) (dissemination of current prices absolutely prohibited; past price information permitted under specified conditions); consent decree, United States v. Electrical Solderless Service Connector Institute, U.S.D.C.S.D.N.Y., Dkt. No. I2-2I7 (Jan. 4, I94I) (institute enjoined from disseminating information concerning prices other than those in actually consummated sales or bona fide contracts to sell). 
current price information, although recognizing explicitly that reports of existing prices were not merely reports of past events. ${ }^{49}$

The Sugar Institute case did make clear that price filing would be viewed unfavorably if there was any obligation not to depart from filed prices. Such a requirement is coercive and so is inconsistent with true competition. An agreement to abide by a filed price, when, in fact, all prices are apt to be identical, and an agreement to adhere to prices contained in a price list circulated by a trade association are much alike.$^{\circ \circ}$ The thrust of the rule is that participants in a price-filing program should be perfectly free to modify their prices without being subject to the necessity of waiting for a specified period until the proposed change can go into effect, a period during which the changer may be subject to persuasion and intimidation. In this connection, the freedom of members of the Tag Manufacturers Institute to sell "off list" was a significant factor in causing the court to reverse the FTC's finding of conspiracy in restraint of competition.

Thus, open-price systems are at least presumptively unlawful when future prices are transmitted ${ }^{s x}$ or when members agree to adhere to filed prices. Current price reporting is presumptively valid, even though reports of the industry average price may serve to indicate what each participant in a collusive scheme is to charge..$^{2}$ The government is required to prove the underlying scheme because the courts are convinced that the "beneficial and curative agency of publicity should not be unnecessarily hampered." ${ }_{53}$ In the case of current price information, however, the contribution to competition seems inconsequential. The reports typically are not released until individual firms have announced their prices to the trade. ${ }^{4} 4$ Moreover sellers are able to get price information from buyers, as is indicated by the recent statement of a prominent steel executive: "It is an amazing thing. If somebody in the steel industry makes a change in price, it is all through the steel industry before noon if it has been made that morning, the information coming from the customers." ${ }^{\prime 55}$ Further, it has been

49 Tag Manufacturers Institute v. FTC, I74 F. 2d 452, 457, 463 (C.A. Ist, I949).

so Compare FTC v. Pacific States Paper Ass'n, 273 U.S. 52 (I927).

sx This does not mean that circulation of current prices that will continue into the future renders the plan presumptively invalid.

s2 This is especially true in industries like the tag industry where are sold a great variety of products made up of various combinations of basic parts. Reports of the prevailing price of the components provide a ready-made pricing formula without which price-fixing would be difficult if not impossible. Compare complaint, United States v. National Container Ass'n, U.S.D.C.S.D.N.Y., Dkt. No. 8-318 (April 20, 1940).

s3 Sugar Institute v. United States, 297 U.S. 553, 601 (1936).

54 Pearce, op. cit. supra note 5 , at 199: "Characteristically, price lists are forwarded to the association office only after or at the time they are issued to the trade by the individual members."

ss Statement of Ernest T. Weir, Chairman, National Steel Corp. in Hearings before House Subcommittee on Study of Monopoly Power, 8rst Cong. ad Sess. Part 4A (Steel), at 820 (1950). 
persuasively argued that competition, far from depending on complete knowledge of prices, thrives on ignorance among sellers. The sense of this proposition is that a seller's propensity to lower his price will be greater if he feels there is a reasonable chance that it will not immediately be matched by his competitors..$^{66}$

In a scientific age trade association attempts to establish uniform costaccounting methods have received friendly treatment by the courts. Sometimes, however, such cost-accounting programs have emphasized uniformity to the extent that little room was left for individual determination of items of cost. ${ }^{57}$ Where that is the case, the cost-accounting program presumably is directed at enabling sellers to compute uniform selling prices and so is strong evidence of an unlawful arrangement. Thus while a trade association may introduce and encourage the adoption of uniform cost-accounting methods, it is important that the figures used in the accounting process be based on actual experience of the firm rather than on arbitrary or fictitious information supplied by the association..$^{8} \mathrm{~A}$ number of recent consent decrees have enjoined the promotion of uniform cost-accounting systems..$^{59}$

The practice of disseminating average-cost figures has accompanied the growth of cost accounting, and, allegedly, technical economies have resulted. The Maple Flooring case established the legality of reporting of industry cost figures, at least so long as reporting plants were unidentified, the data was generally available, and the computations were accurately made. ${ }^{60}$ Underlying this encouragement of dissemination of cost figures is the belief that it is beneficial to competition, but little support for that notion is offered by the actual practice of the Maple Flooring Association during the I920's. Periodically the Association would announce the average costs of producing various grades of lumber in test runs made in several unnamed mills, the results being consolidated and considered as one. To supplement this, the Association distributed average delivered-cost charts which showed the average cost plus freight to destinations throughout the United States from Cadillac, Michigan. The Court recognized that this kind of information "could be made the basis of fixing prices

${ }^{56}$ See Adelman, Effective Competition and the Anti-trust Laws, 6x Harv. L. Rev. I 289, I299 (I948): "Some uncertainty, some good gambling chance that price cuts will not be immediately met, is necessary for effective competition."

57 See note I2 supra.

${ }^{8}$ See consent decree, United States v. W. C. Bell Services, U.S.D.C. Colo., Dkt. No. 380 (Oct. 27, I94I); consent decree, United States v. National Container Ass'n, U.S.D.C.S.D. N.Y., Dkt. No. 8-3I8 (April 20, 1940).

59 United States v. Wallpaper Institute, U.S.D.C.E.D. Pa., Dkt. No. 862 I (June 8, I950); United States v. West Coast Lumbermen's Ass'n, U.S.D.C.S.D. Cal. Cent. Div., Dkt. No. r488-Y (April r6, 194I); United States v. Western Pine Ass'n, U.S.D.C.S.D. Cal. Cent. Div., Dkt. No. I389-RJ (Feb. 6, I94I).

${ }^{60}$ Other restrictions attending statistical programs have been relaxed in connection with cost statistics. Discussion of cost information was allowed in the Maple Flooring case, and Sugar Institute indicated that it may not be required that cost data be made available to buyers. 
or for an agreement for price maintenance," but it did not find evidence in the record that the information had been so used. A number of letters found in the record, however, strongly suggest that competition had little vitality among the maple flooring producers. For example, one producer suggested a meeting to go over the market situation "especially since we have had complaints... of greatly cut prices... that we may be able to trace out";6r while another wrote, "I immediately got in touch with him and explained the unfairness of doing this [reducing prices] without it being brought up in meeting and properly discussed so that any change could be put in effect by all at once." significant that in the leading case approving dissemination of cost information there should be such convincing evidence that something other than competition was being served by the statistics.

It is also highly probable that group and industry average-cost figures in other situations have not benefited competition. Allegedly they lead to adoption of techniques which resulted in cost savings for the low-cost firms, ${ }^{6_{3}}$ but processes economical for one firm would not necessarily be so for others with their own unique problems of location, size, and personnel. Moreover, when the reporting firms are unidentified as the law requires, it becomes impossible to associate low costs with particular processes and techniques. Knowledge that his costs are greater than the industry average is not necessary to encourage competitive producers to reduce costs since it always pays him to operate as efficiently as possible. The general situation has been described as follows: "The primary purpose in compiling average-cost data is to encourage study of individual costs, but too often there is a reverse effect, the manufacturer using average costs for the industry to arrive at a sales figure for his product. ..."'64 It appears that the association distributing cost figures should have the burden of proving a purpose consistent with competition.

Dissemination of inventory and production statistics have frequently been components of "open competition" plans. Their purpose, ostensibly, is to enable members of the industry to follow a "realistic" production policy by virtue of knowing the true supply and demand situation. In line with the prevailing attitude that dissemination of information that makes economic behavior more rational is to be encouraged, distribution of such data is presumed lawful except in special cases. ${ }^{65}$ This is true in spite of the fact that production data may be of

6x Gov't Exhibit No. 5x-2.

62 Gov't Exhibit No. 5 r-E.E.

${ }^{6}$ See Pearce, op. cit. supra note 5 , at 286 . This survey describes briefly some situations where cost studies were used for this purpose, and the results reported by the association staffs.

${ }^{64} \mathrm{Mbid}$., at 28I, quoted from Dept. of Commerce, Trade Association Activities 34 (I927).

65 The American Column \& Lumber case indicated that production reports accompanied by comment and analysis at association meetings are evidence of noncompetitive behavior, particularly when individual firms are identified. Estimates of future production have been held unlawful as a device for assigning production quotas. Hartford-Empire Co. v. United 
considerable value in implementing a scheme of market control. When individual and industry outputs are computed, and there is a concerted undertaking to restrict production, individual firms will be encouraged to cooperate if the figures disclose that their percentage of the total has not declined. ${ }^{66}$ Or production and inventory statistics may reflect (or show) brighter business prospects and thereby serve to deter particular firms from increased sales efforts when sales are falling off. ${ }^{67}$ Where there is a division of the market with each firm assigned a fixed percentage, production figures of the industry enable the computation of individual quotas.

Like price and cost information, production and inventory statistics make most economic sense in other than a competitive context. The business forecasts invariably implied by, if not expressed in conjunction with, this information are the kind which under competition are made independently by individual enterprisers. Central judgment attempts to replace individual decision. If competition is active, the forecasts will be ignored and production determined according to the estimates of the individual, in which case the statistics are useless. If the industry, no longer competitive, takes its cue from the information supplied by the central office, it is plain that there is scant reason to encourage the dissemination of this type of information.

\section{III}

As a practical matter trade associations may not be as free to collect and disseminate prices and trade statistics as the precedents indicate. Slight changes in the facts presented to the court may justify an inference of conspiracy to fix prices, although the statistical operations themselves are not basically different from those approved in the cases. The anti-trust division continues to bring indictments and complaints against associations which seem to have complied with the technical requirements laid down in the cases. ${ }^{68}$ These suits usually end in consent decrees and are never litigated. This may mean that the associations are insecure enough about the legality of what they are doing to wish to avoid an adverse decision that might be used against them in a suit for treble damages.

States, 323 U.S. 386,427 (I945). When production data is presented in juxtaposition to representations of "normal" production or of orders and shipments so that the expected production policy can be easily inferred, there may be evidence to support an inference of illegal behavior. See complaint, United States v. West Coast Lumbermen's Ass'n, U.S.D.C.S.D. Cal. Cent. Div., Dkt. No. 1488-Y (April 16, I941); complaint, United States v. Western Pine Ass'n, U.S.D.C.S.D. Cal. Cent. Div., Dkt. No. 1389-RJ (Feb. 6, 194r).

${ }^{66}$ See Jones, op. cit. supra note 3 , at $47-48$; Burns, op. cit. supra note 2 , at 58.

67 See American Column \& Lumber Co. v. United States, 257 U.S. 377, 405 (192r).

${ }^{68}$ The indictments and complaints, of course, charge price-fixing which has never been condoned in the cases; but as to the statistical programs, there is frequently no charge that the data was kept secret, that it disclosed individual positions, that there was excessive supervision, that there was unauthorized comment and discussion, or that adherence to filed prices was required. 
It may mean that the cost of litigation is prohibitive in light of the value of the statistical exchange for legitimate or illegitimate purposes. The main significance of the consent decrees is as testimony that adherence to the lines established in the cases is no guarantee of freedom from the risks of anti-trust prosecution.

That too much confidence is not to be reposed in prior judicial pronouncements is well illustrated by the Cement Institute case decided by the Supreme Court in $1948 .{ }^{69}$ Respondents were the same producers that comprised the defendant association in the Cement Manufacturers case in which the association was exonerated of any unlawful practices. In the intervening period there was no material change in the activities carried on, but in Count I of the complaint the price-fixing charge was made explicit and new evidence was presented in support of it. Startling identity of bids and evidence of coercive measures taken against noncomplying producers were among the factors setting the two cases apart and enabling the Court to sustain the Commission's finding of a combination to fix prices via a multiple basing-point system. ${ }^{\circ 0}$ While the Cement Institute case was partly a basing-point price-discrimination case, it was also a price-fixing case and the implications for trade associations are clear. New evidence may cause the demise of a previously accepted system of statistical reporting. However, the burden of proving the underlying conspiracy remains with the prosecution. If, in view of the obvious utility of such statistics for restrictive purposes and their scant value to competition, "open competition" were to be made presumptively invalid, trade-association sponsors of such programs would have to be prepared to prove their innocence. In many areas the public would benefit.

${ }^{69}$ FTC v. Cement Institute, 333 U.S. 683 (1948).

zo Ibid., at $7 \mathrm{r} 6$. 